\title{
Analysis of currents on the continental shelf off the Santa Catarina Island through measured data
}

\section{Análise das correntes na plataforma continental ao largo da Ilha de Santa Catarina através de dados medidos}

\author{
Anna Luiza Pacheco Dalbosco ${ }^{1 *}$ (D), Davide Franco ${ }^{1}$ (D), Rodrigo do Carmo Barletta ${ }^{2}$ (D) \& Alexandre Bach Trevisan ${ }^{3}$ (D) \\ ${ }^{1}$ Universidade Federal de Santa Catarina, Florianópolis, SC, Brasil \\ ${ }^{2}$ Aster Engenharia, Florianópolis, SC, Brasil \\ ${ }^{3}$ Companhia Catarinense de Águas e Saneamento, Florianópolis, SC, Brasil \\ E-mails: aldalbosco@gmail.com (ALPD), d.franco.ocean@gmail.com (DF), barletta@astergeo.com.br (RCB), atrevisan@casan.com.br (ABT)
}

Received: October 28, 2018 - Revised: September 17, 2019 - Accepted October 28, 2019

\begin{abstract}
The coastal currents and forcing agents that conduct them are still little-known in the internal continental shelf of Santa Catarina. Therefore, this work aimed to analyze the data of currents measured off the Island of Santa Catarina in order to better comprehend its patterns and forcing agents. The three measuring stations were installed in shallow water near the Arvoredo Biological Marine Reserve (ST01), Jurerê Beach (ST02) and Ingleses Beach (ST03). Data were collected by a current meter from January 22, 2014 to December 17, 2014. In the consisted data set, it was performed a basic statistical analysis, spectral decomposition and harmonic analysis in the tide components. All the stations presented a resulting southward flow, especially the station next to Arvoredo Marine Biological Reserve (ST01). The meteorological forcing has a strong contribution to the magnitude and direction of component $\mathrm{v}$ (alongshore). While the tidal component has greater importance in the cross-shore flow (component $\mathrm{u}$ ). The wind showed a strong correlation with currents and the local level, indicating to be the main forcing agent of the flow in the subtidal frequency.
\end{abstract}

Keywords: Coastal hydrodynamics; Measured data; Spectral decomposition.

\section{RESUMO}

As correntes costeiras e as forçantes que as regem ainda são pouco conhecidas na plataforma continental interna de Santa Catarina. Por isso, este trabalha teve como objetivo analisar os dados de correntes medidos ao largo da Ilha de Santa Catarina a fim de compreender melhor os seus padrões e forçamentos. As três estações de medição foram instaladas em águas rasas próximas à Reserva Marinha Biológica do Arvoredo (ST01), Praia de Jurerê (ST02) e Praia dos Ingleses (ST03). Os dados foram coletados por um medidor de correntes no período compreendido entre 22/01/2014 à 17/12/2014. No conjunto de dados consistido foi realizada uma análise estatística básica, decomposição espectral e análise harmônica nas componentes de maré. Todas as estações apresentaram um escoamento resultante para sul, especialmente a estação próxima a Reserva Biológica Marinha o Arvoredo (ST01). A forçante meteorológica possui forte contribuição na magnitude e direção da componente v (ao longo da costa). Enquanto a componente mareal tem maior importância no fluxo através da costa (componente u). O vento apresentou uma forte correlação com as correntes e o nível local, indicando ser a forçante principal do escoamento na frequência submareal.

Palavras-chave: Hidrodinâmica costeira; Dados medidos; Decomposição espectral. 


\section{INTRODUCTION}

Hydrodynamic patterns of the continental shelf conduct the environmental and economic aspects of coastal regions such as fishing, sedimentary dynamics, nutrient availability, navigation, dispersion of pollutants, among others (Halpern et al., 2008; Mann \& Lazier, 2006). However, the circulation in these regions is forced by agents of different scales (temporal and spatial), natures and intensities, besides the influence of bottom and coastal morphology (Mitchell et al., 2015; Noernberg \& Alberti, 2014). It makes the knowledge of processes in shallow environments much more complex.

The circulation of the oceans in the South Brazilian Bight (SBB, which comprehend the region between Cabo Frio/RJ and Cabo de Santa Marta/SC) has been well studied and documented in recent years, especially through regional numerical models (Stech \& Lorenzzetti, 1992; Mesquita \& Harari, 2003; Souza \& Robinson, 2004; Palma et al., 2004; Calado et al., 2008; Palma et al., 2008; Oliveira et al., 2009; Matano et al., 2010; Lima et al., 2013; Pereira et al., 2013). On the other hand, hydrodynamic studies with measured data on the South Brazilian Bight (SBB) remain scarce. In the 1990s, the project entitled "Estudos Ambientais em Áreas Oceânicas e Costeiras da Região Sul do País" (Environmental Studies in Oceanic and Coastal Areas of the Southern Region of the Country) carried out by PETROBRAS in partnership with universities raised the first series of data with more consistency for the region. There were 11 months of data collected by 3 current logs at 30, 75 and 130 meters deep (Casares Pinto, 1998; Hirata, 2008). After this survey, indirect measurements (Pimenta et al., 2006) or of short length (Cirano \& Lessa, 2007) were documented. In 2014 a survey of oceanographic data was carried out around the north/northeast region of Santa Catarina Island in order to generate funds for the implantation of a submarine emissary in the region (Barletta et al., 2016; Bleninger et al., 2016). Part of this dataset is used in this study.

The SBB comprises an extension of approximately $350 \mathrm{~km}$ between latitudes $26^{\circ}$ and $29^{\circ} 20^{\prime} \mathrm{S}$ and it is inserted in the SBB. The current in the SBB has a dominant flow to southwest, with weaker currents during autumn and more intense in spring (Casares Pinto, 1998; Palma et al., 2008). In summer, predominant flows to southeast generate resurgence, whereas in autumn and winter more periods of inversion of this pattern occur, with currents flowing to north and generating subsidence (Pimenta et al., 2006; Cecílio, 2006).

Currently, it is believed that the meteorological forcing is the one that controls the currents in the region, and the transient meteorological conditions (like the passage of cold fronts) are more important than seasonal wind patterns (Harari et al., 2011). However, wind loses importance in less exposed environments, such as the west region of Santa Catarina Island, where the astronomical tide becomes more relevant in the local outflow (Barletta et al., 2016). For Casares Pinto (1998), the longshore flow to the bathymetry is dominated by subtidal frequency events, whereas the cross-shore flow presents a greater influence of the tide. However, other authors also attribute to the Brazilian Current (BC) an important role in determining the circulation in SBB (Hirata, 2008; Palma et al., 2008).

Although the studies cited indicate a relationship between the pattern of currents in the SBB and forcing agents that rule it, there is still a need for more direct and concrete analysis of these relationships. This study therefore aims to describe the behavior of currents in the SBB and to analyze its relationship with wind and local level.

\section{MATERIALS AND METHODS}

The study region is located in the Internal Continental Shelf of Santa Catarina and comprises the north of Santa Catarina Island (SCI) and Arvoredo Marine Biological Reserve (ReBioMar Arvoredo). Current velocity, sea level, and background temperature data were obtained from the measurement of three ADCPs (Acoustic Doppler Current Profile). One ADCP (ST01) was anchored at ReBioMar Arvoredo and the other two (STO2 and ST03) in the north of SCI (Figure 1 and Table 1). Data from the north of SCI were collected by the Companhia Catarinense de Águas e Saneamento (CASAN) to elaborate studies for the implantation of submarine outfalls in the region (Barletta et al., 2016; Bleninger et al., 2016). The ADCP funded at Arvoredo Reserve is part of the Environmental Monitoring Project of the Arvoredo Reserve - MAArE Project (Segal et al., 2017). The project was executed between 2013 and 2017 with fundings from PETROBRAS in partnership with the Federal University of Santa Catarina (UFSC) and the Arvoredo Reserve technical team.

All three devices were installed on the seabed with transducers pointed to the surface. The ADCP of ST01 station was anchored to a depth of 21.4 meters in a metal structure of approximately 1 meter. It has been configured to record data in 1-meter cells along the water column with $0.5 \mathrm{~m}$ blank distance, $1 \mathrm{~Hz}$ acquisition rate, 300 second sampling time and 1-hour sampling interval. With these settings the first measured cell was 2 meters from the bottom (structure + blank distance $+1 / 2$ cell size). Because this first cell was excluded in the consistency analysis, the first valid cell from ST01 collected data at a depth of 3 meters (Table 2).

The ADCPs of ST02 and ST03 stations were installed in $0.86 \mathrm{~m}$ metal structures at a depth of 11 and 20 meters, respectively. Differing the sampling settings of station ST01 only in sampling interval, which was 30 minutes. The first cell measured by these ADCPs was at a distance of $1.86 \mathrm{~m}$ from the bottom (Table 2).

The measured data went through a consistency analysis and quality control, as well as correction in the magnetic declination. For ST01, ST02 and ST03, 16, 6 and 15 cells were validated, respectively. From the dataset, the period between 01/22/2014 and $12 / 17 / 2014$ (328 days) was cut for analysis because it is the

Table 1. Information about collected data stations.

\begin{tabular}{cccc}
\hline Station & Location & Geographic Coordinates & Sample rate interval \\
\hline ST01 & Arvoredo Reserve & $27^{\circ} 15^{\prime} 11.46^{\prime \prime} 48^{\circ} 24^{\prime} 04,37^{\prime \prime}$ & $300 \mathrm{~s} / 1$ hour \\
ST02 & Jurerê Beach & $27^{\circ} 23^{\prime} 57.48^{\prime \prime} 48^{\circ} 27^{\prime} 55.80^{\prime \prime}$ & $300 \mathrm{~s} / 1 / 2 \mathrm{hour}$ \\
ST03 & Ingleses Beach & $27^{\circ} 25^{\prime} 17.40^{\prime \prime} 48^{\circ} 21^{\prime} 57.96^{\prime \prime}$ & $300 \mathrm{~s} / 1 / 2 \mathrm{hour}$ \\
\hline
\end{tabular}




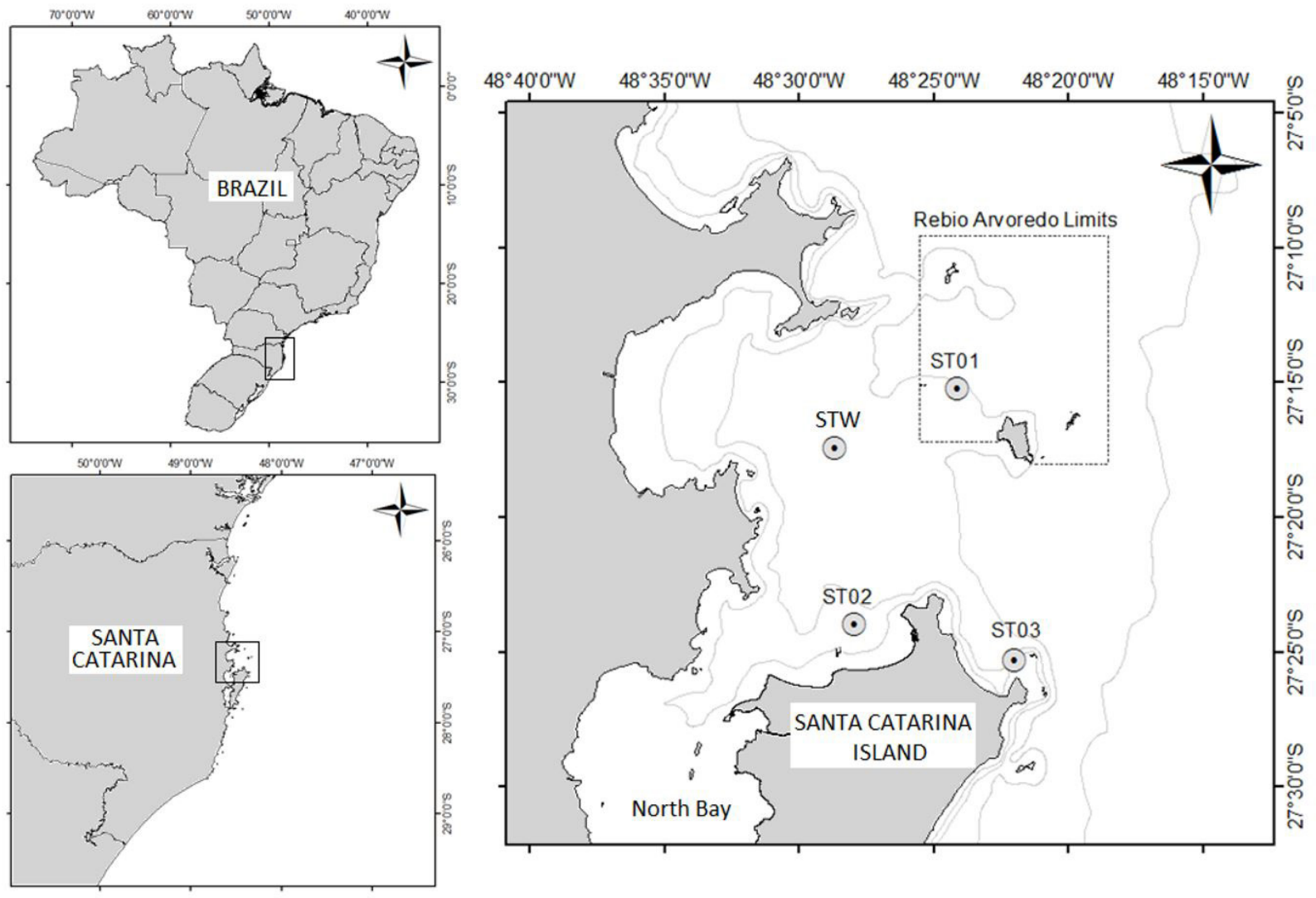

Figure 1. Study area and collected data stations. Where ST01, ST02 e ST03 refer to measured data by ADCP, and STW to the point of extraction of wind data.

Table 2. Distance (in meters) from the bottom to the center of ADCP measurements cells. For layer analysis, where all cells were not present, a mean bottom layer (dark gray), middle layer (gray) and surface layer (light gray) were performed.

\begin{tabular}{ccccc}
\hline \multirow{2}{*}{ Cell } & \multicolumn{3}{c}{ Distance from the bottom } \\
\cline { 2 - 4 } & ST01 & ST02 & ST03 \\
\hline 1 & 3 & 1.86 & 1.86 \\
2 & 4 & 2.86 & 2.86 \\
3 & 5 & 3.86 & 3.86 \\
4 & 6 & 4.86 & 4.86 \\
5 & 7 & 5.86 & 5.86 \\
6 & 8 & 6.86 & 6.86 \\
7 & 9 & - & 7.86 \\
8 & 10 & - & 8.86 \\
9 & 11 & - & 9.86 \\
10 & 12 & - & 10.86 \\
11 & 13 & - & 11.86 \\
12 & 14 & - & 12.86 \\
13 & 15 & - & 13.86 \\
14 & 16 & - & 14.86 \\
15 & 17 & - & 15.86 \\
16 & 18 & - & - \\
\hline
\end{tabular}

period with the largest number of data collected simultaneously by the three stations. The currents were analyzed in their barotropic condition (mean value for the entire measured water column) and baroclinic condition (layer analysis) (Table 2).
After data consistency, basic statistical analysis and spectral decomposition of the series were performed. For the spectral decomposition of the observed current velocity time series (Yo) was used a classical frequency decomposition technique. The hourly series of currents measured by the ADCP were decomposed into independent components. Initially the tidal component (Yt) was identified through the t_tide package (Pawlowicz et al., 2002) developed for use in MATLAB. Subtracting the tidal component from the total signal, we have the non-tidal component $(\mathrm{Ynt}=\mathrm{Yo}-\mathrm{Yt}$ ). This component contains important contributions in the day and week range (synoptic scale) and seasonal scale, but it still maintains high frequency residual (Yres). To identify and exclude this high frequency component, the low-pass filter LP33 (Flagg et al., 1976; Beardsley et al., 1985) was applied, resulting in the subtidal component $($ Ysubt $=$ Ynt - Yres $)$. The filtered subtidal component (without the high frequency residual) now represents scales of meteorological and seasonal processes.

Energy distribution of the observed current series, non-tidal and subtidal, was analyzed by estimating power spectrum. For this, it was used the consolidated Welch's method, with 50\% overlap and Hamming window. As the three measured data series (ST01, ST02 and ST03) have significant holes, for each series a 114-day period was extracted with consistent data and few failures to perform this analysis. A 38-day window has been set.

After descriptive and spectral analysis of currents, linear correlation analysis (Pearson) was performed for the total period of measured data, in order to better understand the relationship 
between local hydrodynamic patterns and atmospheric and astronomical forcing, and cross correlation for a cutout time series. The excerpt of the series to be analyzed was defined aiming to understand a period of influence of two atmospheric systems that act in the region: wind N-NE (South Atlantic Subtropical Anticyclone - SASH) and wind S (Anticyclone of polar origin, which originates the called cold front). It was used the methodology proposed by Rodrigues et al. (2004) to identify cold fronts on the

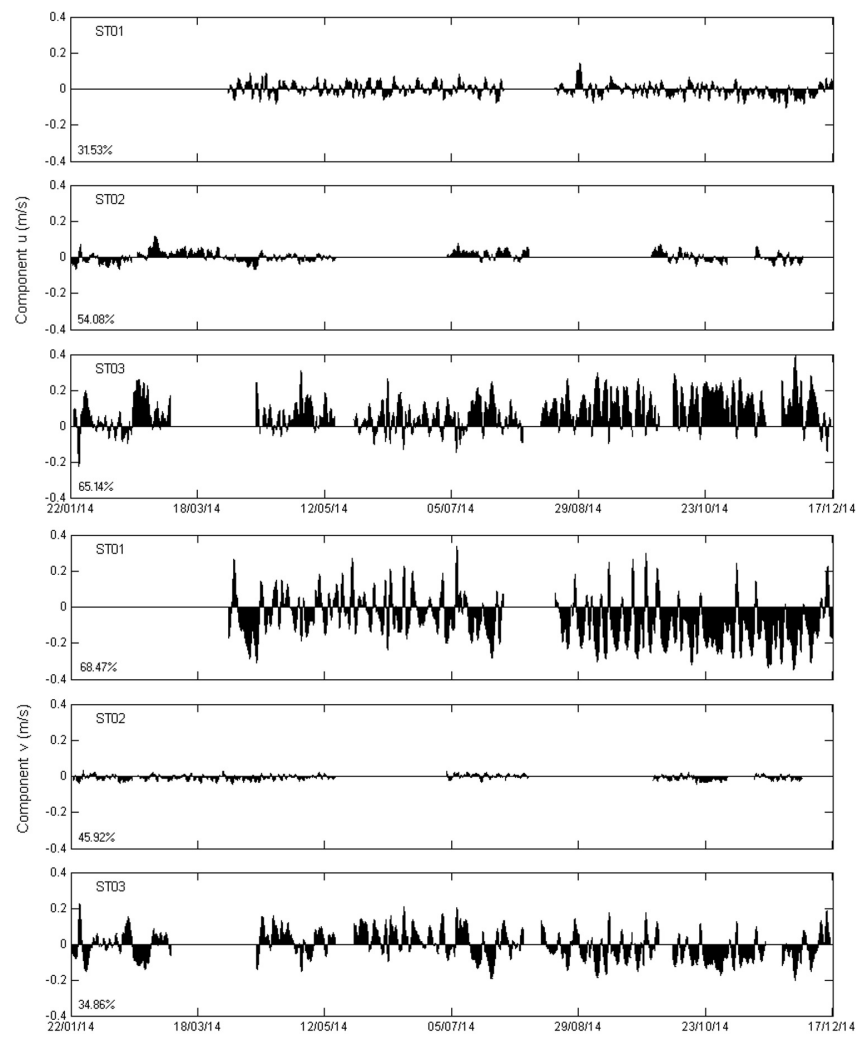

Figure 2. Time series of the daily mean for all cells of components $\mathrm{u}$ and v stations ST01, ST02 and ST03, and contribution percentages of each component for current magnitude. time series of wind data. After identifying cold fronts, a period was chosen in which currents had been measured simultaneously in the three stations.

Wind data with a 6-hour temporal resolution were obtained from version 2 of the Climate Forecast System reanalysis model (CFSv2 - NCEP; Saha et al., 2014). The series was extracted at the closest possible point to the ADCP's anchored stations (STW, Figure 1). And, to check the temperature pattern along the water column at the points measured by the ADCP, a surface temperature series was also extracted from the STW point. The sea surface temperature series was collected from the OSTIA database provided by the National Oceanic and Atmospheric Administration (NOAA). The data have daily and spatial temporal resolution of $0.05^{\circ}(\sim 6 \mathrm{~km})$.

\section{RESULTS AND DISCUSSIONS}

Time series of measured data, already validated, showed temporal coverage of $66.8 \%$ for ST01, $67.8 \%$ for ST02 and $80.8 \%$ for ST03. The most significant periods of data shortages at all three stations occurred because of equipment configuration problems or equipment loss due to trawling activity common in the region.

Figure 2 shows the barotropic current velocity series (mean of the entire water column) in component u (zonal, east-west) and component $\mathrm{v}$ (southern, north-south). For ST01, located in ReBioMar Arvoredo, the current presented higher intensity in component $\mathrm{v}$ (alongshore) with predominance of southward flow. The average current magnitude at this station was $0.177 \mathrm{~m} / \mathrm{s}$, with a contribution of $68.47 \%$ in component $\mathrm{v}$ and $31.53 \%$ in component $u$. This directional pattern of current in ST01, flowing predominantly in the north-south axis, can be seen in Figure 3.

For component $\mathrm{u}$, the maximum positive velocity (to the east) was $0.37 \mathrm{~m} / \mathrm{s}$ and the negative maximum velocity (to the west) was $0.44 \mathrm{~m} / \mathrm{s}$. In addition to similar intensities, these currents (east/west) also had balanced percentage of occurrence (Table 3 and Figure 2). By analyzing the component $\mathrm{u}$ along the water column (Figure 4) it was found that the balance between east/west currents is not in a distribution over time, but in a reversal of direction between

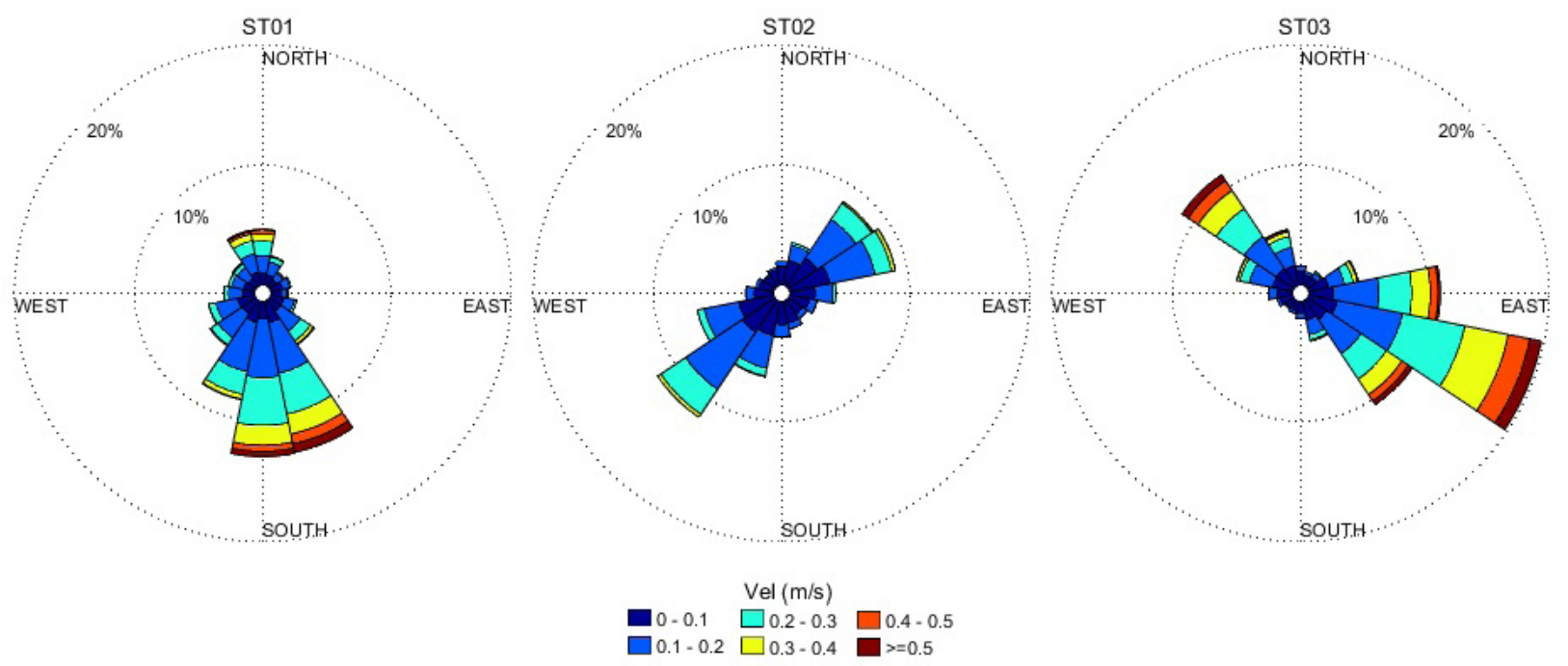

Figure 3. Current rose for the entire water column for the stations ST01, ST02 and ST03. 
Table 3. Average, minimum and maximum values of current magnitude and velocities $(\mathrm{m} / \mathrm{s})$ in the component $\mathrm{u}$ (east-west) and $\mathrm{v}$ (north-south) components measured in the three stations. (Stand. Dev $=$ Standard Deviation, Contr.u or $\mathrm{v}=$ Contribution in component $\mathrm{u}$ or $\mathrm{v}, \mathrm{Sp}=$ spring, $\mathrm{Su}=\mathrm{Summer}, \mathrm{Au}=$ autumn, Wi $=$ Winter, $\mathrm{W}=$ West, $\mathrm{E}=$ East, $\mathrm{N}=$ North, $\mathrm{S}=$ South).

\begin{tabular}{|c|c|c|c|c|}
\hline \multicolumn{2}{|c|}{ Parameters } & ST01 & ST02 & ST03 \\
\hline \multirow[t]{10}{*}{ Current magnitude } & Average & 0.163 & 0.102 & 0.182 \\
\hline & Median & 0.148 & 0.089 & 0.154 \\
\hline & Maximum & 1.006 & 0.491 & 0.910 \\
\hline & Stand. Dev. & 0.092 & 0.065 & 0.128 \\
\hline & Average Sp & 0.213 & 0.105 & 0.208 \\
\hline & Average $S_{u}$ & - & 0.123 & 0.196 \\
\hline & Average $A u$ & 0.148 & 0.108 & 0.184 \\
\hline & Average $W i$ & 0.171 & 0.115 & 0.188 \\
\hline & Contr. u & $31.53 \%$ & $54.08 \%$ & $65.14 \%$ \\
\hline & Contr.v & $68.47 \%$ & $45.92 \%$ & $34.86 \%$ \\
\hline \multirow[t]{7}{*}{ Velocity in $u$} & Average & -0.003 & 0.004 & 0.077 \\
\hline & Average $W$ & 0.076 & 0.077 & 0.116 \\
\hline & Average $E$ & 0.073 & 0.084 & 0.178 \\
\hline & Average $W$ & 0.441 & 0.321 & 0.601 \\
\hline & Average $\mathrm{E}$ & 0.373 & 0.429 & 0.798 \\
\hline & Occurrence $W$ & $50.61 \%$ & $49.33 \%$ & $32.96 \%$ \\
\hline & Occurrence E & $49.39 \%$ & $50.67 \%$ & $67.04 \%$ \\
\hline \multirow[t]{7}{*}{ Velocity in $v$} & Average & 0.145 & 0.070 & 0.098 \\
\hline & Average S & 0.162 & 0.076 & 0.093 \\
\hline & Average $N$ & 0.129 & 0.064 & 0.103 \\
\hline & Average $S$ & 1.013 & 0.376 & 0.629 \\
\hline & Average N & 0.762 & 0.307 & 0.677 \\
\hline & Occurrence $S$ & $72.26 \%$ & $55.70 \%$ & $59.62 \%$ \\
\hline & Occurrence $N$ & $27.74 \%$ & $44.30 \%$ & $40.38 \%$ \\
\hline
\end{tabular}

the layers. The currents were predominantly east on the surface and west on the bottom layer. Component $\mathrm{v}$ presented positive mean velocity (north) of $0.762 \mathrm{~m} / \mathrm{s}$ and negative velocity (south) of $1.013 \mathrm{~m} / \mathrm{s}$. In addition to being more intense, the southward component $\mathrm{v}$ was also the most frequent in the measured period. Throughout the layers (Figure 4) it can be noticed that southward flowing currents (negative) have greater intensity on the surface that will be gradually reduced to the bottom. Flowing north current (positive) has a constant intensity along the water column.

In ST02, the current had a maximum magnitude of $0.491 \mathrm{~m} / \mathrm{s}$ and an average of $0.113 \mathrm{~m} / \mathrm{s}$, with balanced contribution of components $\mathrm{u}$ and $\mathrm{v}$ (Table 3 ). For component $\mathrm{u}$, the positive values (to the east) were more intense. For component v, the negative (south) currents were stronger and more frequent (55.70\%). The directional pattern of this station occurs northeast-southwest (Figure 3), resulting in mean runoff to the south quadrant. Along the water column, as in ST01, it was possible to identify predominance of currents to northeast in the surface and southwest in the bottom (Figure 4).

The current at ST03 presented the highest average magnitude $(0.194 \mathrm{~m} / \mathrm{s})$ and the highest intensities in the $\mathrm{u}$ component (east-west) among three analyzed stations. For component u, maximum speed to the east was $0.798 \mathrm{~m} / \mathrm{s}$, and to the west was $0.601 \mathrm{~m} / \mathrm{s}$. In addition to being more intense, the eastward current was also approximately 2 times more frequent than the westward currents throughout the measured period (Table 3 and Figure 2). Component v presented very similar average south and north speeds of 0.677 and $0.629 \mathrm{~m} / \mathrm{s}$ respectively, with higher frequency for southward currents. The flow at this station was northwest-southeast direction (Figure 3). In contrast to ST01 and ST02, ST03's current was uniform across the layers in both magnitude and direction (Figure 4). There is a natural weakening of the magnitude of the current in cells closer to the bottom, but in the analyzed period, no inversions of direction along the water column were identified.

Because these measurements are performed in shallow environment and near islands and mainland, velocity and direction of measured flow were strongly influenced by local geomorphology. Percentages of contribution of components $\mathrm{u}$ and $\mathrm{v}$ in the current's magnitude (Table 3), quite different for 3 stations, portray this. In ST01, the current flows in north-south directions, alongshore, and suffers interference from the islands that form the ReBioMar Arvoredo. Due to its proximity to the north of Santa Catarina Island and North Bay channel, ST02 has its flow in northeast-southwest direction, being part of the ebb and flood current. As to ST03 being in a narrow region between the coast of Santa Catarina Island and a promontory and two small islands to east and south (Figure 1). This configuration causes runoff at this station to be limited mostly to northwest-southeast direction (Figure 3). The geomorphology only draws the main flow paths (north-south axis) and softens or intensifies velocities (Cecílio, 2006; Palma et al., 2008). Other forcing agents, which will be discussed later, are responsible for the characterization of the flows themselves.

The average velocity of component $\mathrm{v}$ found in ST01 $(0.14 \mathrm{~m} / \mathrm{s})$ was similar to those found by Zavialov et al. (2002) in the external platform of Rio Grande do Sul $(0.16 \mathrm{~m} / \mathrm{s})$ and Casares Pinto (1998) in the internal platform of Santa Catarina $(0.12 \mathrm{~m} / \mathrm{s})$. The ST03 has its intensity divided between components $\mathrm{u}$ and $\mathrm{v}$, however in average, the magnitude is close to the values found in ST01. The mean magnitude found in ST02 $(0.10 \mathrm{~m} / \mathrm{s})$ approximates the values measured by Garbossa et al. (2014) in the North Bay of Santa Catarina Island $(0.11 \mathrm{~m} / \mathrm{s})$.

In seasonal analysis, it was observed that in ST01 and ST03 there was greater variation in velocity and directional pattern between stations (Table 3 and Figure 5).

In these two stations, the highest intensities occurred in spring, with predominance of currents flowing to the south quadrant, corroborating the seasonal pattern identified by Casares Pinto (1998) and Palma et al. (2004). In autumn, in addition to milder currents, the currents showed a resulting average northward flow in all measured cells (Figure 6). In ST02, in all seasons of the year, the current maintained its magnitude and direction pattern, with values more intense in summer (Table 3 and Figure 5). This indicates the highest degree of protection of this region, especially the forcing agents coming from the south and east, typical from autumn and winter (Monteiro, 2001).

Seasonal modulation identified in current data can be observed most intensely in surface and bottom water temperature series (Figure 7). It is possible to notice an intense stratification of the water column in summer and spring months, and homogenization of the column during winter and autumn. Seasonality of water 

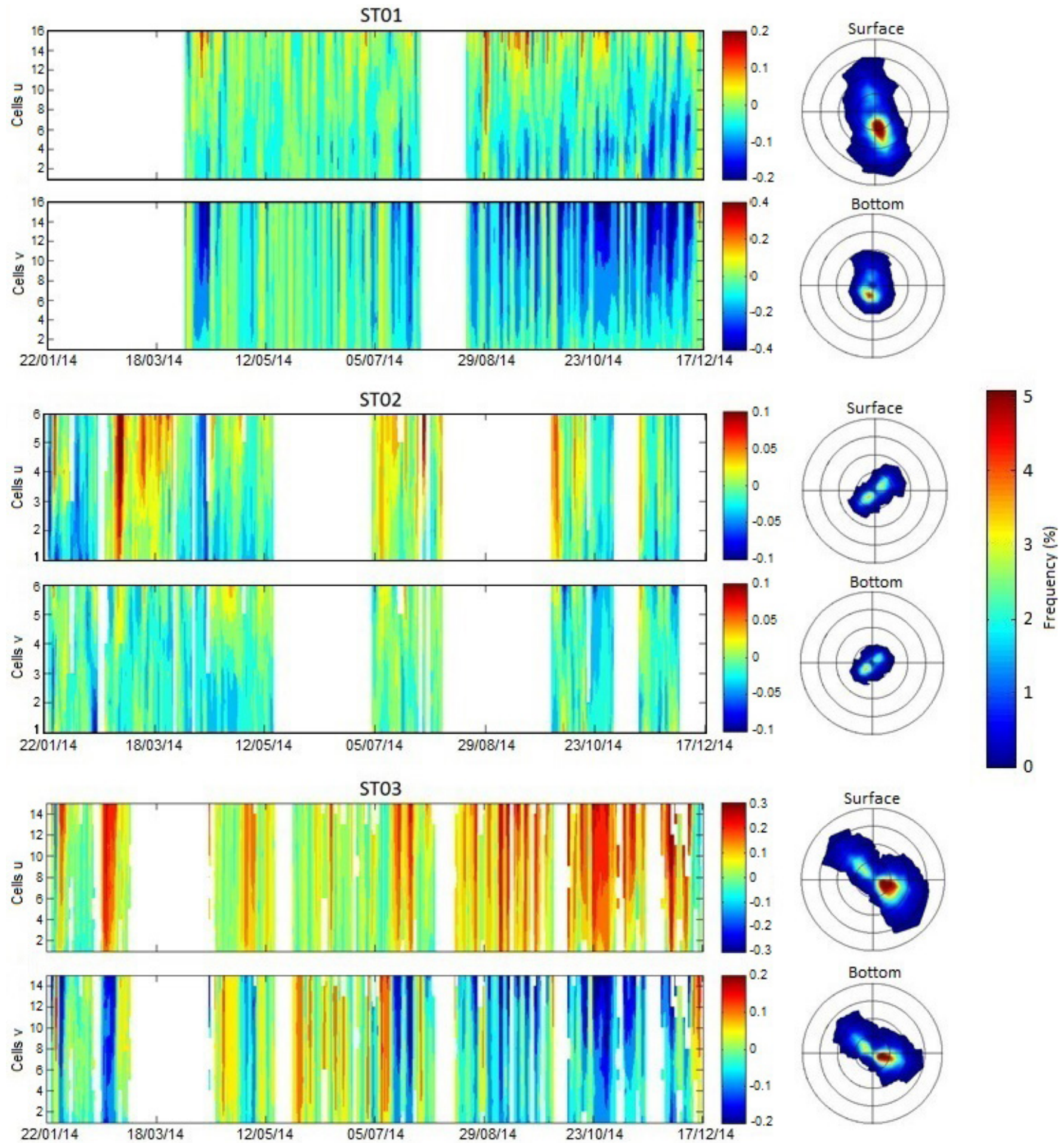

Figure 4. Current speed (m/s) with two-day filter in all measured valid cells, for stations ST01, ST02, ST03. And velocity ocurrence polar diagram in the surface and bottom layer, the circles refers to velocities $0.25,0.50,0.75$ and $1.0 \mathrm{~m} / \mathrm{s}$.

thermal patterns is directly related to seasonality of current patterns. As previously mentioned, in summer and spring the currents to south and southeast intensify in baroclinic character. The higher velocity of surface currents, and declination by Ekman. In consequence, surface water flows into ocean region, generating subsidence zones along the coast. In order to correct the formed sea level gradient, current flows toward the shore through the bottom layer, also leading low-temperature water, that commonly occupy the middle and outer shelf. Thus, generating the observed thermal gradient. This seasonal pattern of stratification and homogenization of the water column has been previously identified by studies in the continental shelf of Santa Catarina (Hille et al., 2008; Carvalho et al., 1998; Bordin et al., 2019).

The power density spectra for the $\mathrm{u}$ and $\mathrm{v}$ components of the currents measured at the three stations are shown in Figure 8. When performing spectral decomposition, the contributions of 

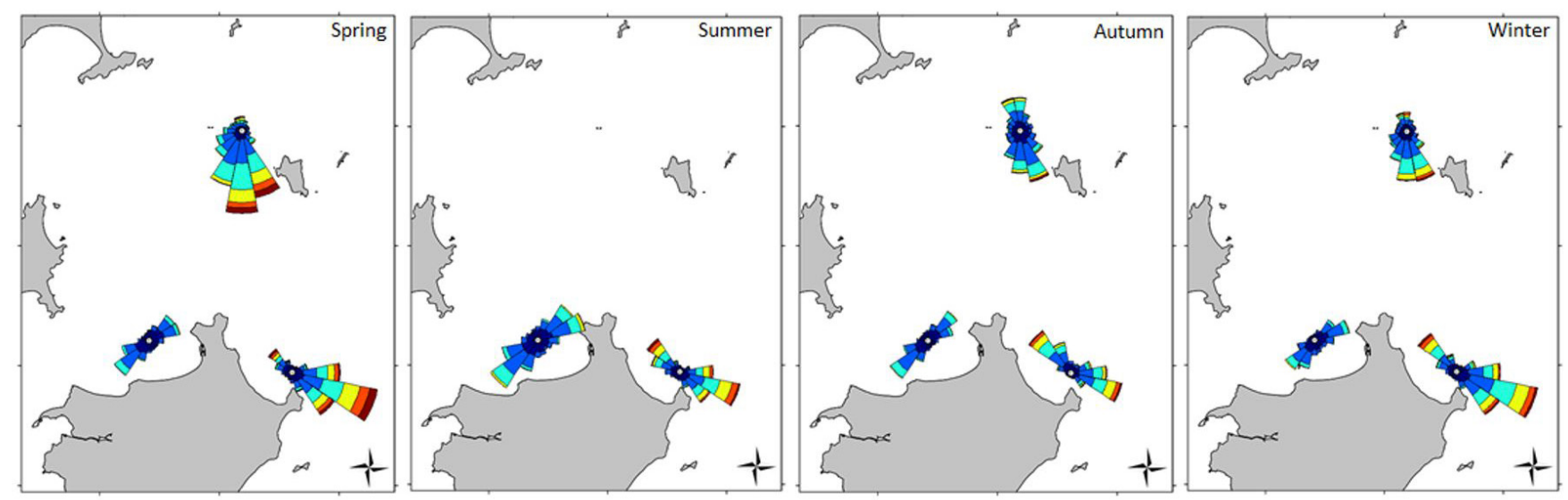

$0.0-0.1$

Velocity $(\mathrm{m} / \mathrm{s})$

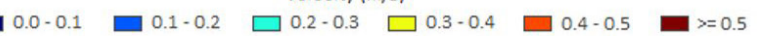

Figure 5. Current rose for each station of the whole water column for the stations ST01, ST02 and ST03.
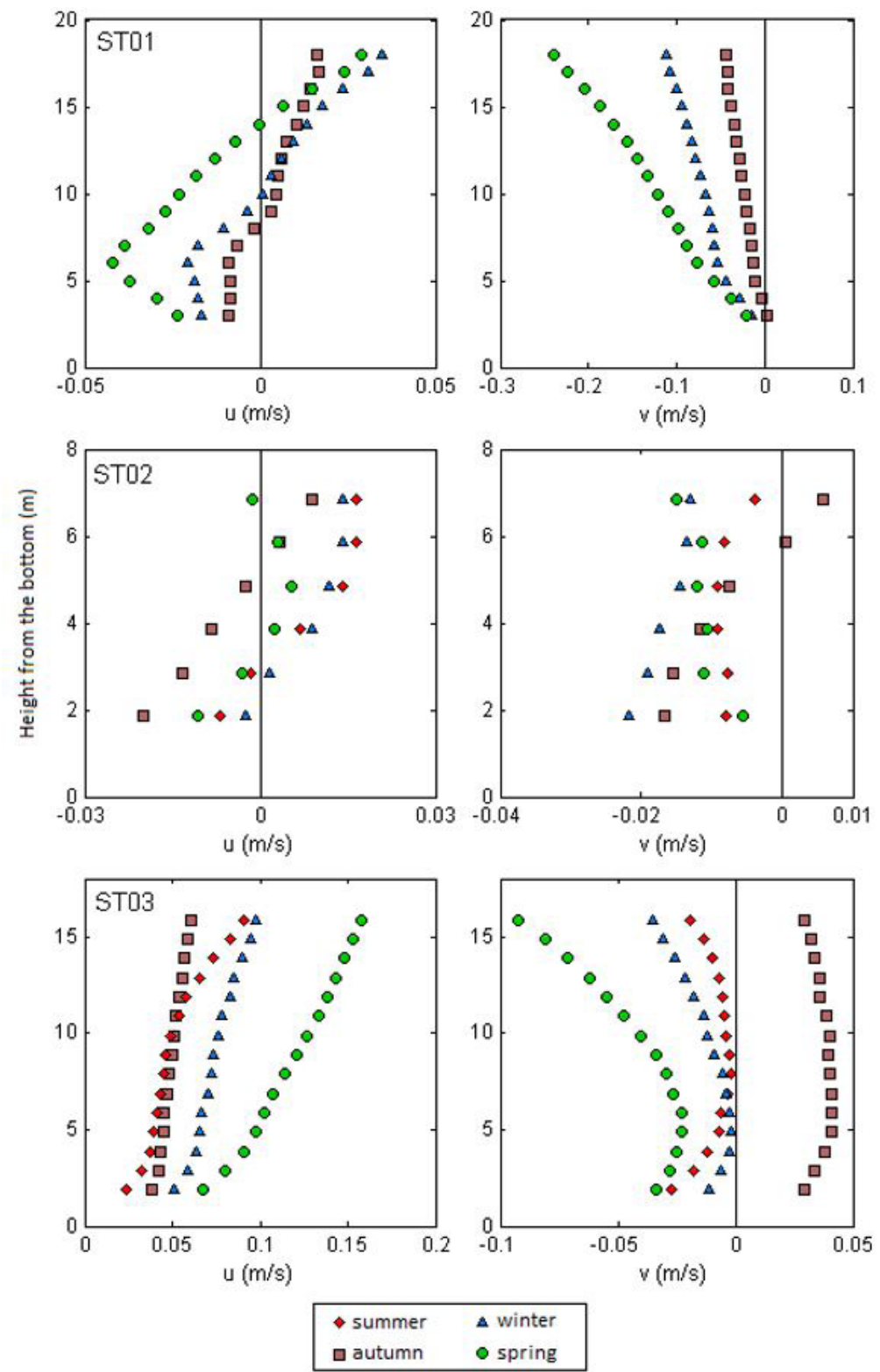

Figure 6. Averages of velocities for component u and v by season for all measured cells along the water column, for stations ST01, ST02 and ST03. 


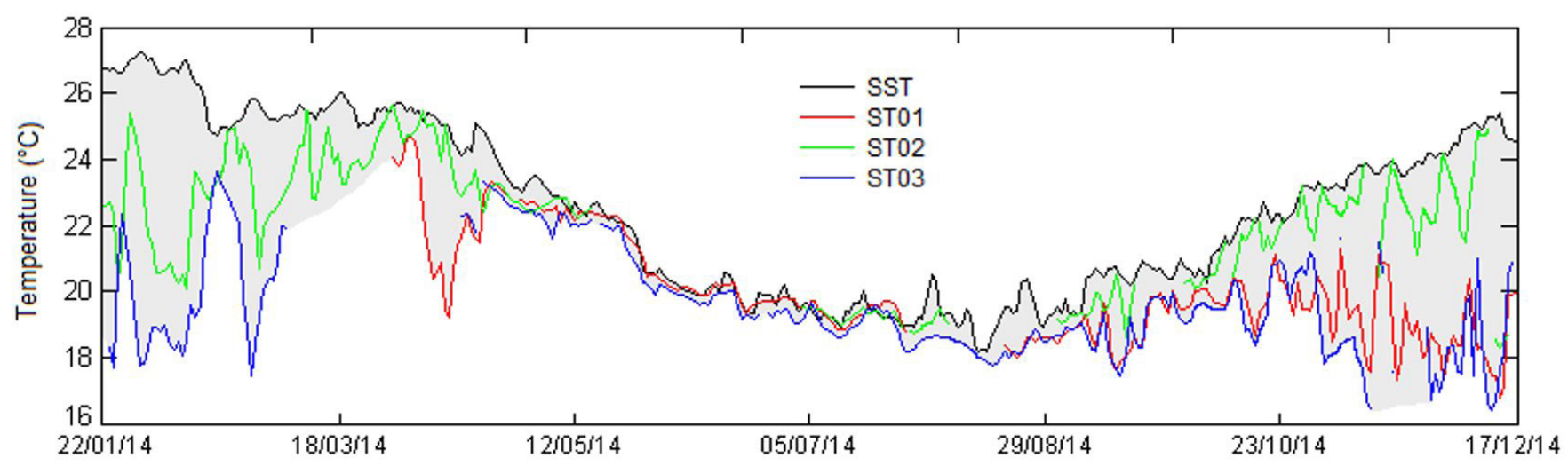

Figure 7. Local surface temperature (black line) and bottom temperature measured by ADCPs at stations ST01 (red line), ST02 (green line) and ST03 (blue line). SST = Sea Surface Temperature.
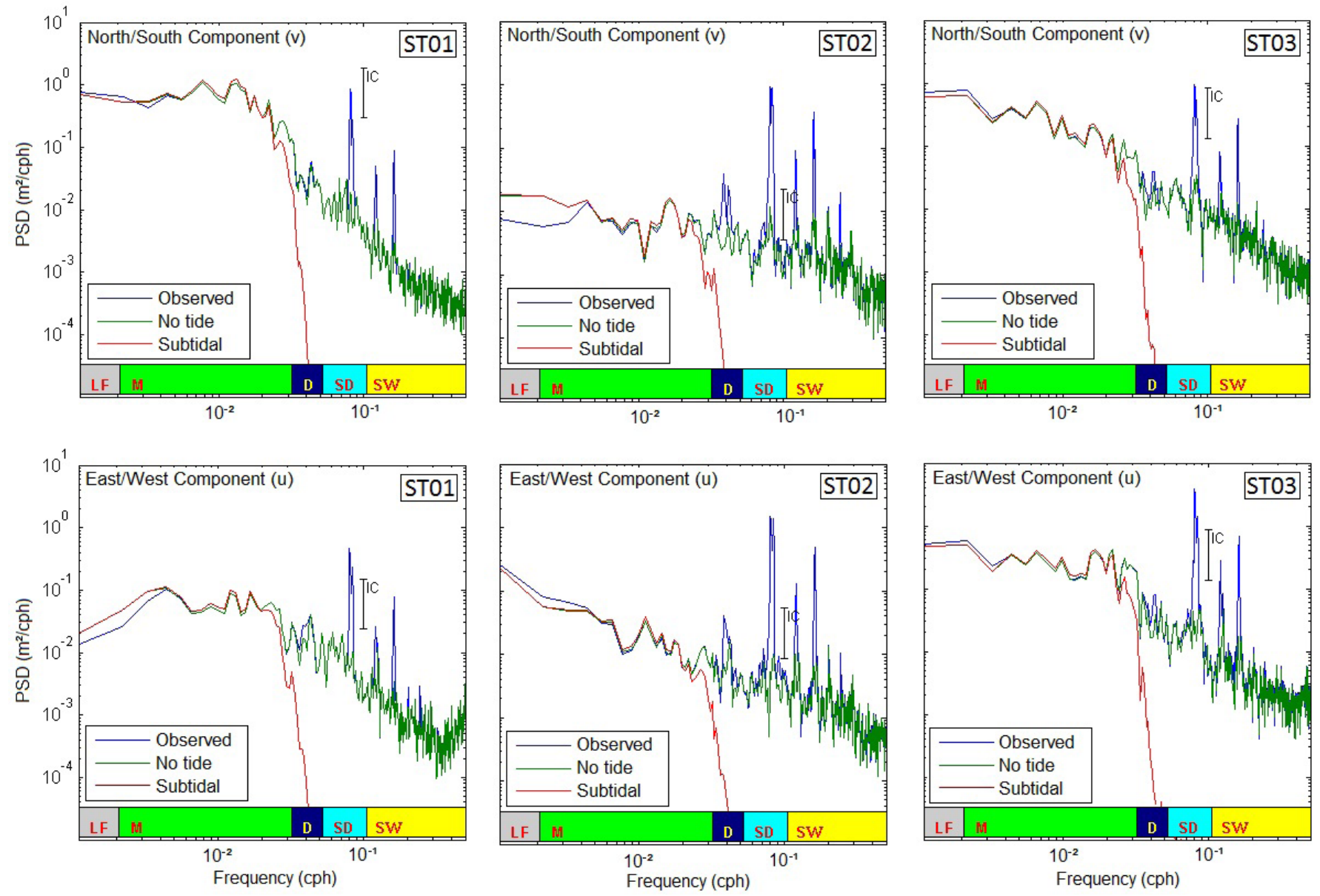

Figure 8. Tidal and subtidal currents obtained from spectral decomposition of the measured barotropic current at stations ST01, ST02 and ST03. PSD = Power Sprectrum Density, LF = Low Frequency, M = Meteorological, SD = Semidurnal, SW = Shallow Water.

the tidal component in the semidiurnal band, $1 / 3$ diurnal and $1 / 4$ diurnal, were evident. The tidal component was less intense in the diurnal band. Also, the subtidal component peaks around 3 days, that corresponds to the duration of the passage of frontal systems in the region. (Gregorio, 2014).

In ST01, component v (north-south) in the subtidal range presented variance (energy) almost 2 times greater than component $\mathrm{u}$ (east-west). Moreover, the energy level in the tidal and subtidal bands in component $\mathrm{v}$ was very distinct, with the subtidal band having greater importance (Table 4 and Figure 8).

In ST02 it was possible to verify a diurnal peak higher than in other stations, and also a greater balance between energy levels of components $u$ and v. And unlike ST01, the tidal band in ST02 is the most important component in the composition of the final 
magnitude of the local current. In ST03 it was possible to identify two well marked peaks around the period of 6 and 10 days for components $u$ and v. Also, greater energy balance between the tidal and subtidal bands was observed.

In the variance decomposition of the subtidal component, it is possible to verify the portions attributed to the meteorological and low frequency component (Table 4). The component in the meteorological band dominates (around $80 \%$ of the explained

Table 4. Decomposition in variance of barotropic current magnitude.

\begin{tabular}{clcc}
\hline Stations & \multicolumn{1}{c}{ Current } & $m 2 / s 2$ & $\%$ \\
\hline ST01 & Observed & 0.0286 & 100 \\
& Tidal & 0.0037 & 12.95 \\
& No Tide & 0.0249 & 87.05 \\
& Subtidal & 0.0221 & 77.26 \\
& Residual & 0.0028 & 9.79 \\
& Subtidal & 0.0221 & 100 \\
& Meteorological & 0.0192 & 86.88 \\
& Low Frequency & 0.0029 & 13.12 \\
ST02 & Observed & 0.0149 & 100 \\
& Tidal & 0.0116 & 77.85 \\
& No Tide & 0.0033 & 22.15 \\
& Subtidal & 0.0016 & 10.74 \\
& Residual & 0.0017 & 11.41 \\
& Subtidal & 0.0016 & 100 \\
& Meteorological & 0.0013 & 81.25 \\
& Low Frequency & 0.0003 & 18.75 \\
ST03 & Observed & 0.0438 & 100 \\
& Tidal & 0.0186 & 42.47 \\
& No Tide & 0.0252 & 57.53 \\
& Subtidal & 0.0185 & 42.28 \\
& Residual & 0.0067 & 15.25 \\
& Subtidal & 0.0185 & 100 \\
& Meteorological & 0.0141 & 76.22 \\
& Low Frequency & 0.0097 & 23.78 \\
\hline \multirow{6}{*}{} & &
\end{tabular}
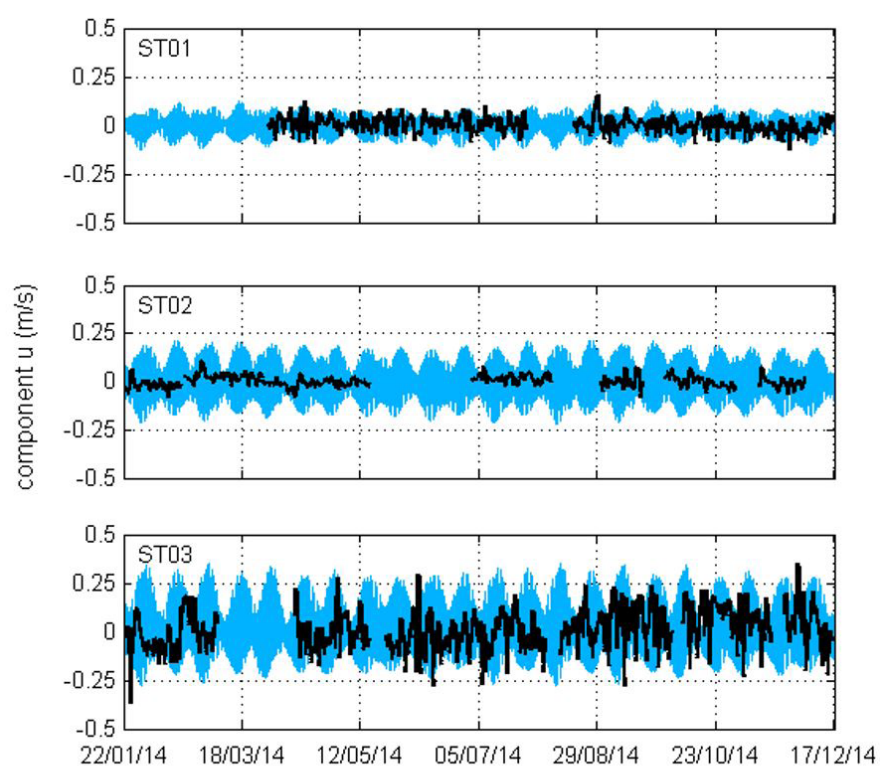

variance) the subtidal frequency. However, the low frequency component also plays an important role, reaching $23 \%$ of the variance explained in ST03.

The influence of the different energy bands, for the $u$ and v components at each measurement point and at different depths, can be better seen in Figure 9 and Figure 10. The importance of the subtidal band for the predominant north/south flow to ST01 is evident, as well as the irrelevance of the subtidal band to the intensity of currents in ST02, and the balance between the tidal and subtidal bands in the composition of the flow patterns in ST03.

It is also clear the importance of the tidal current for the cross-shore flow (u component), already identified in previous studies (Casares Pinto, 1998; Mesquita \& Harari, 2003). In all stations, tidal current in the cross-shore component was more significant than the subtidal current. This fact results an amplification of the tidal current in this component (in ST03, due to local morphology), associated with a lower influence of the subtidal band (in ST01 and ST02). The intensification of tidal currents in shallower areas and with a geomorphology that generates bottlenecks or channels (ST02 and ST03), occurs basically due to mass conservation (Harari \& Camargo, 1998). As to the main influence of the subtidal band on the component $\mathrm{v}$ (north-south), especially in non-sheltered areas, is related to the characteristics of two main atmospheric systems that act in the region: the South Atlantic Subtropical Anticyclones (SASH) and movements of Front Meteorological Systems (FMSs) (Castro \& Miranda, 1998).

The SASH, a high-pressure system located in the Atlantic between South America and Africa, is the determining system in defining the atmospheric condition for the study area (Ito \& Ambrizzi, 2000). The zonal displacement throughout the year sometimes intensifies northeast winds, sometimes weakens them allowing greater penetration of FMSs (Tchernia, 1981). Wind data collected from the STW (Figure 1) indicated that the local wind pattern for the period is characteristic of southern Brazil
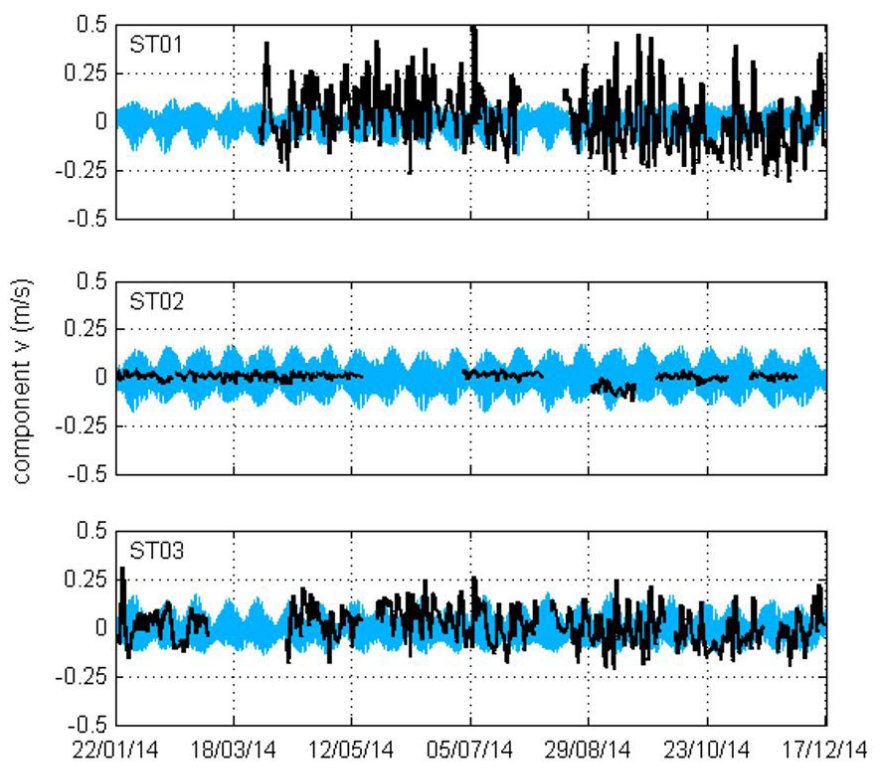

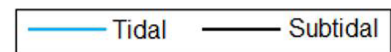

Figure 9. Time series of tidal and subtidal components of stations ST01, ST02 and ST03 for the current velocity. 
(Figure 11). It happens with higher occurrence of N-NE sector winds, but higher wind intensity associated with cold fronts (FMSs). On average, the number of cold fronts is quite similar in all stations, with a slight decrease in summer and a slight increase in winter (Oliveira, 1986; Stech \& Lorenzzetti, 1992; Lemos \& Calbete, 1996; Rodrigues et al., 2004; Barletta et al., 2016).

Linear correlation analyzes between wind (Figure 11), level (Figure 12) and currents allowed us to better understand

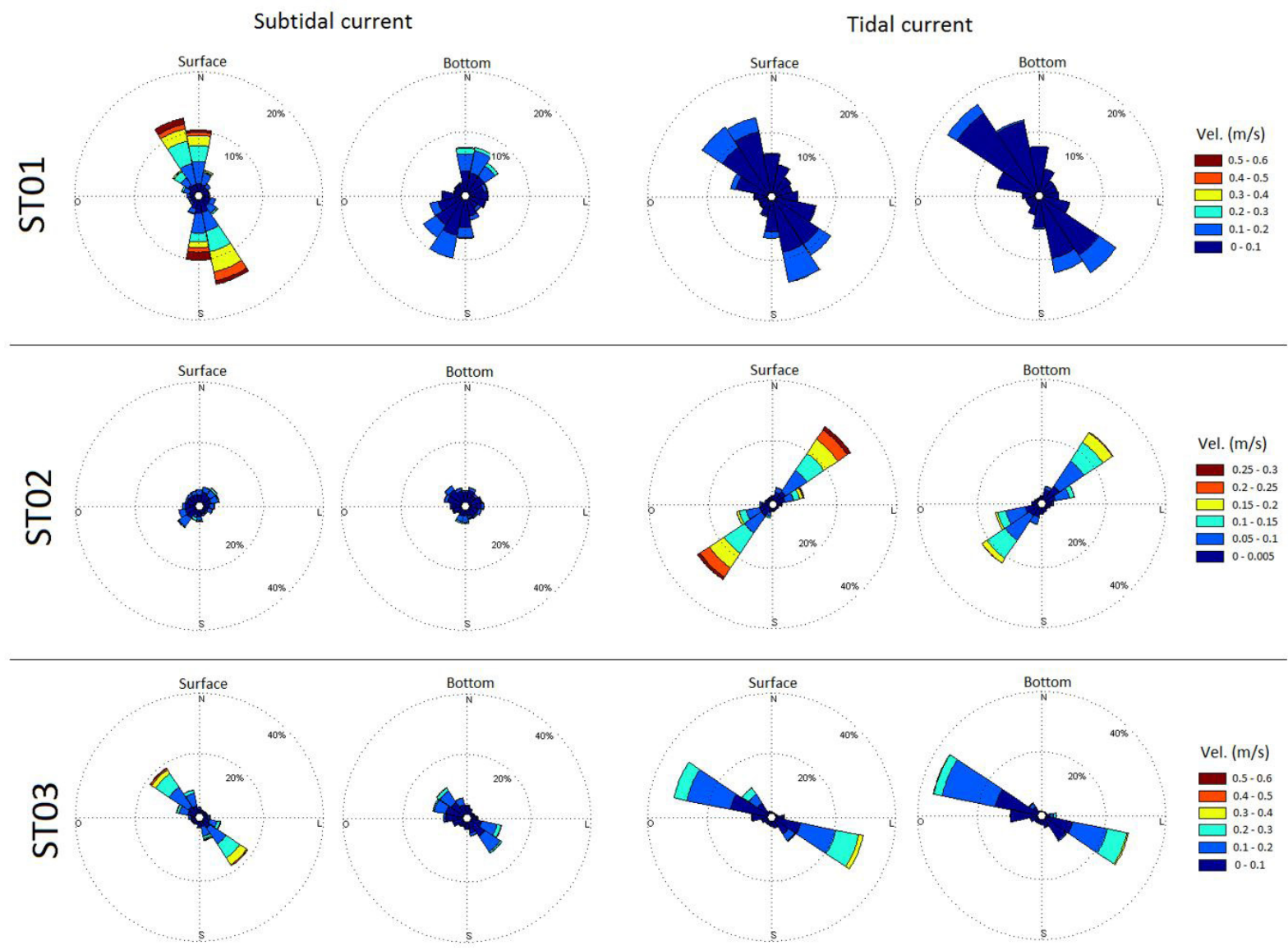

Figure 10. Tidal and subtidal currents rose to the bottom and surface layer of stations ST01, ST02 and ST03.

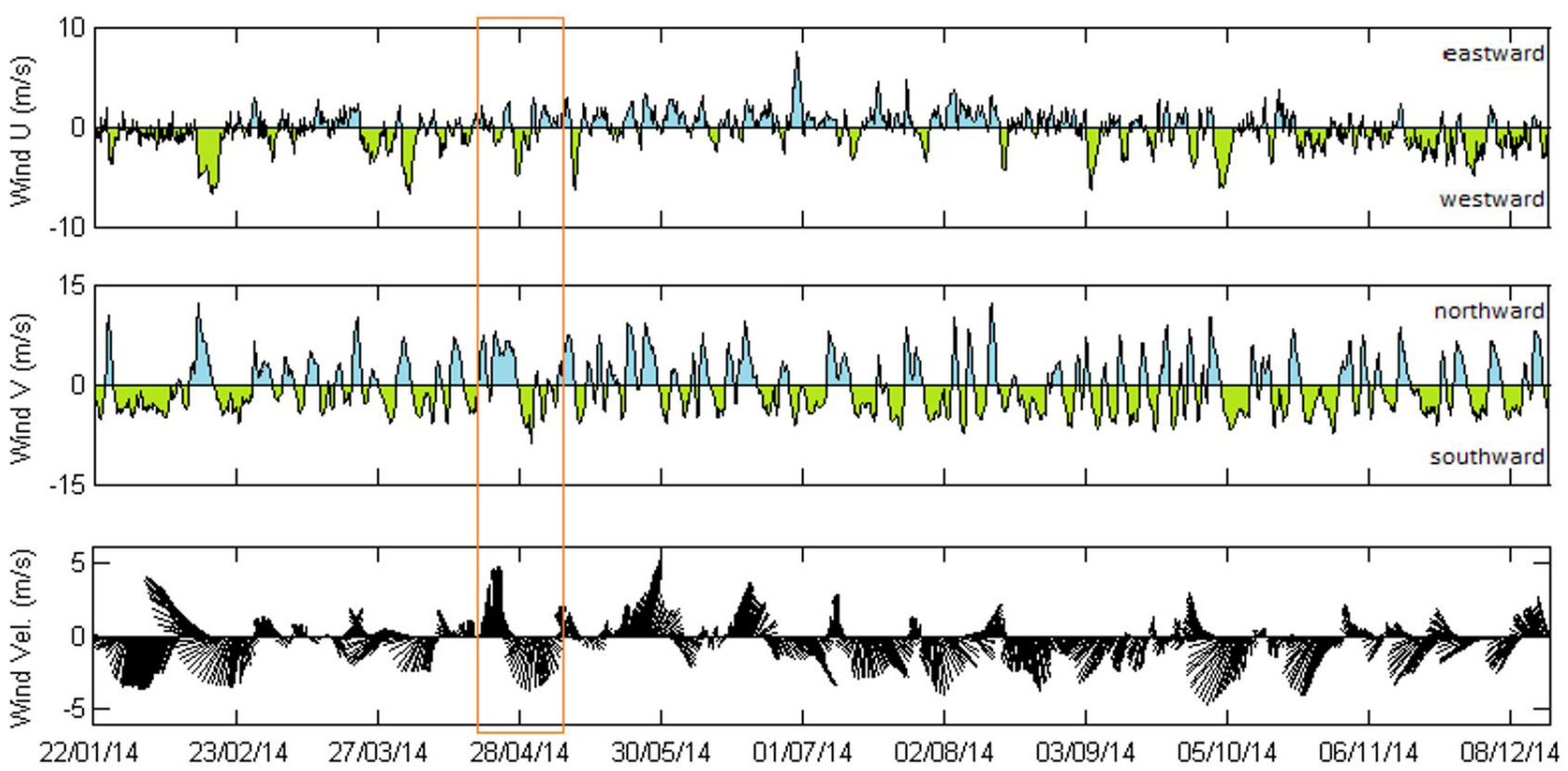

Figure 11. Time series of local wind drawn at the point of extraction wind data (STW) shown in Figure 1. In the upper frame for wind component $u$ velocity $(\mathrm{m} / \mathrm{s})$, in the middle frame for wind component $\mathrm{v}$ velocity $(\mathrm{m} / \mathrm{s})$, and in the lower frame stick-filtered wind velocity $(\mathrm{m} / \mathrm{s})$ chart for 7 days. The portion within the orange rectangle indicates the data series extracted for cross correlation analysis. 
the relationship among the local hydrodynamic pattern and the atmospheric and astronomical forcing agents.

Understanding, more specifically, the local runoff under the influence of usual atmospheric conditions (N-NE wind) and during the cold fronts ( $\mathrm{S}$ wind), cross-correlation analyzes were performed in a section extracted from the total series: from April 22, 2014 to May 03, 2014 (Figures 11 and 12).
Only by visual verification of the selected excerpt it was possible to observe sea level rising and currents flowing north during the cold front, and local level lowering and mean southward flow under usual atmospheric condition (Figure 13). Components $\mathrm{v}$ current and wind (subtidal frequency) presented linear and in-phase correlation in the expressive value of 0.78 for ST01, 0.75 for ST03 and 0.56 for ST02. This high subtidal frequency of

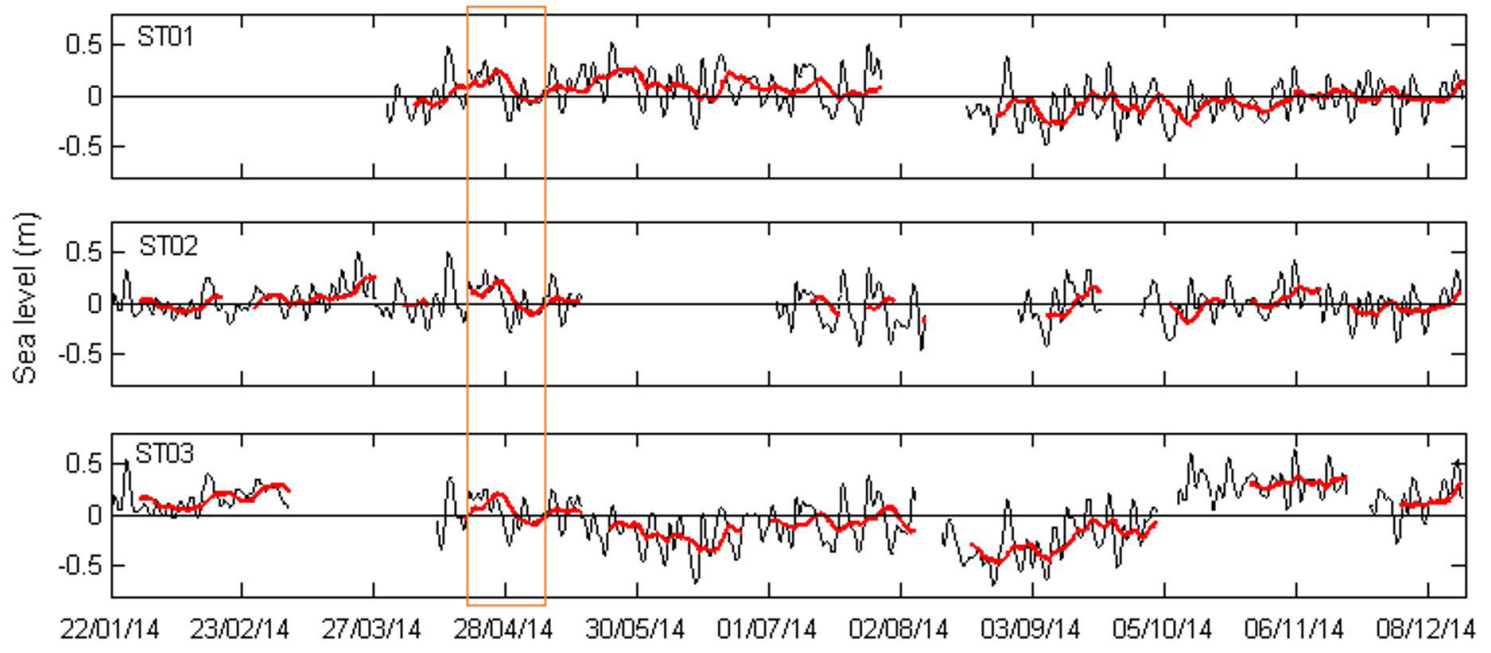

Figure 12. Sea level measured by ADCPs at stations ST01, ST02 and ST03. Black line = level with daily filter; Red line = level with weekly filter. The period within the orange rectangle indicates the extracted data series for cross-correlation analyzes.

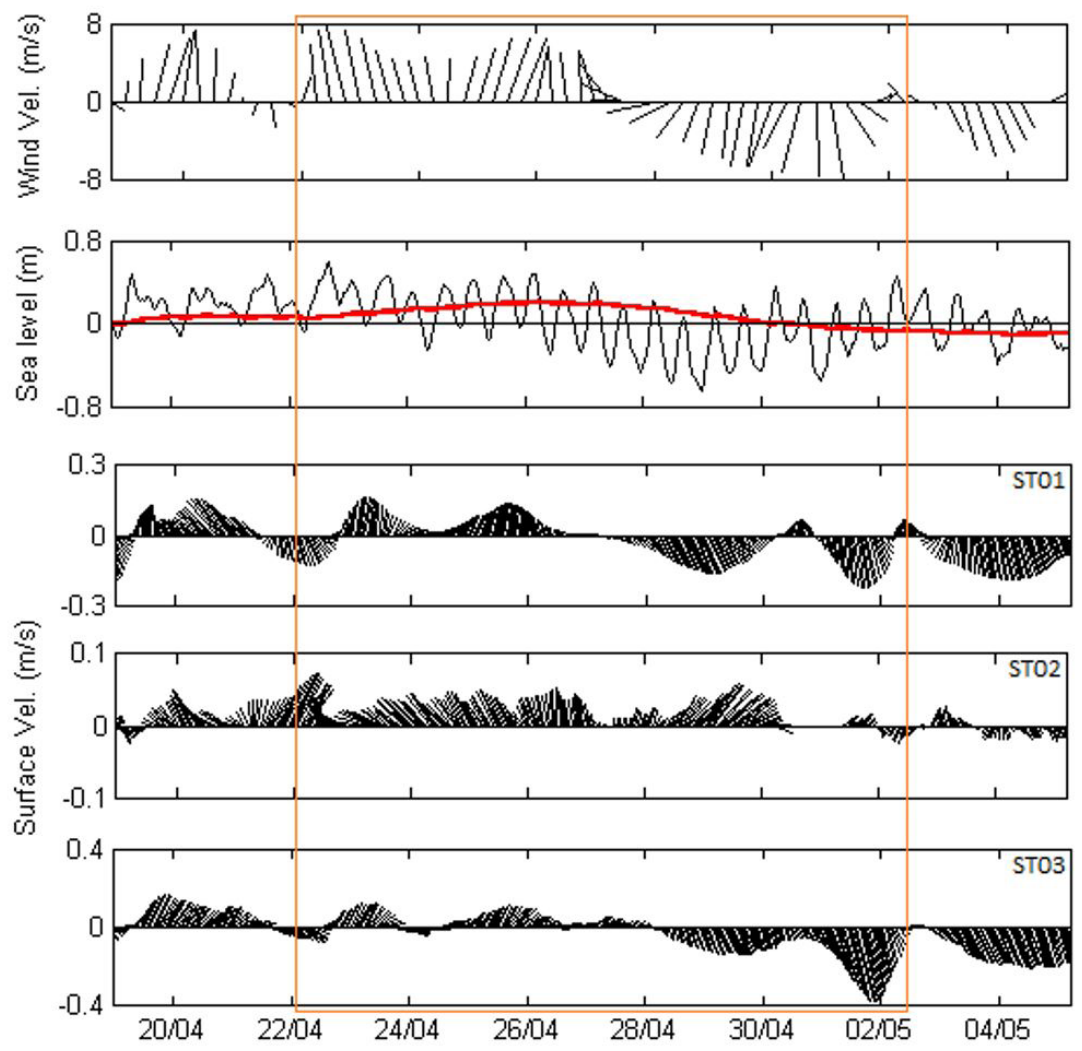

Figure 13. Local wind velocity stickplot $(\mathrm{m} / \mathrm{s})$ in upper frame, low frequency $(7$ days) measured level in second frame and surface current velocity $(\mathrm{m} / \mathrm{s})$ stickplot where positive values indicate north flowing currents and negative currents south flowing. ST02 and ST03 currents have been rotated to their main axis of flow for graphing. The portion within the orange rectangle indicates the data series extracted for cross correlation analysis. 

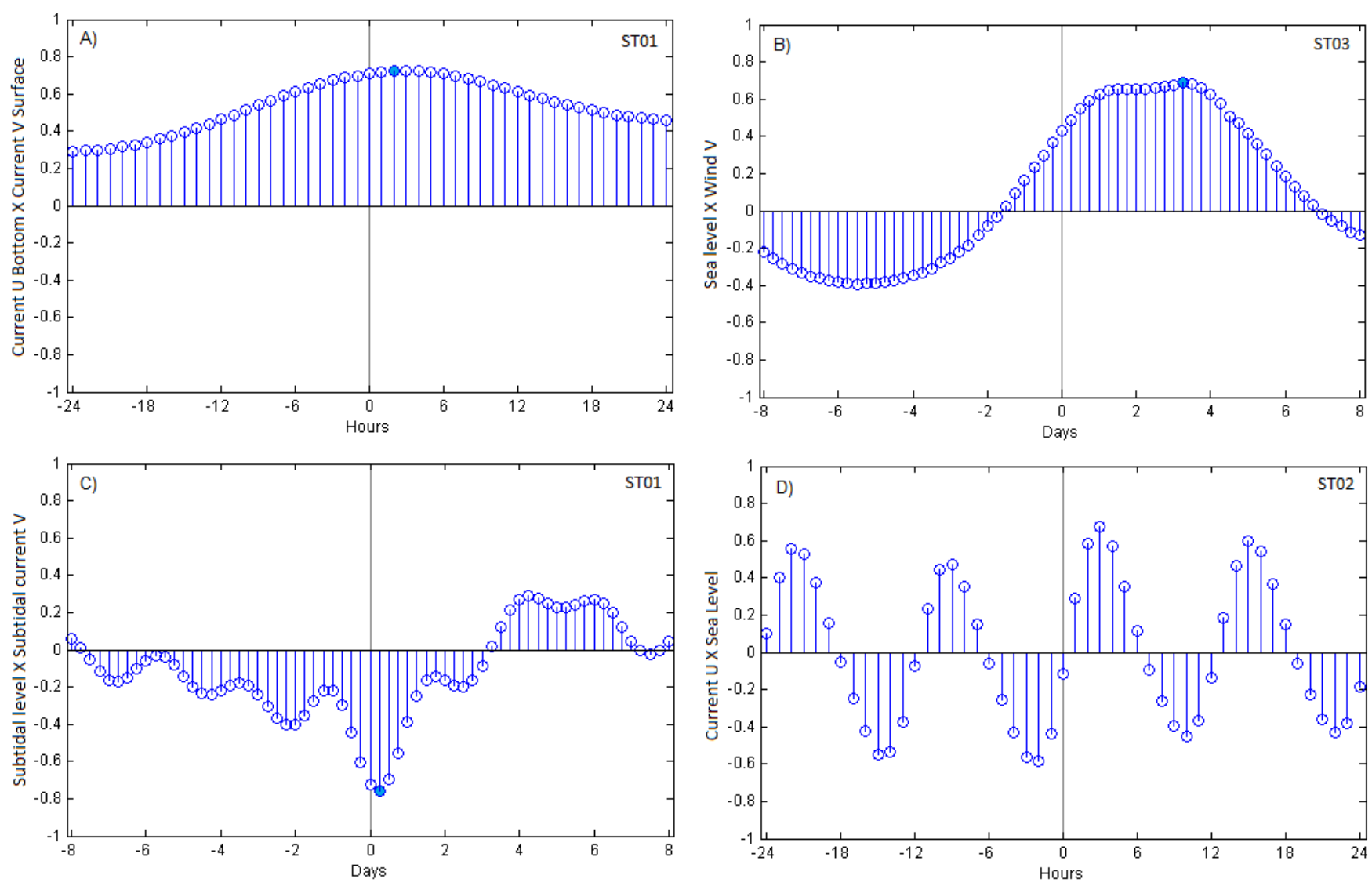

Figure 14. Cross-correlation analyses for a period of the time series (started 22/04/2014): A) component u of bottom current VS component v of surface current (ST01); B) Sea level VS component v of wind (ST03); C) Subtidal level VS component v of subtidal current (ST01); D) component u of current VS Sea level (ST02).

energy in the parallel-to-coast current, especially at stations ST01 and ST03, had already been demonstrated in the spectral analyzes previously performed (Table 4 and Figures 8, 9 and 10). The strong influence of wind on currents over the internal continental shelf has been widely studied (Scott \& Csanady, 1976; Brink, 1991; Lentz, 1994; Palma et al., 2004; Palma et al., 2008). Despite the strong relationship always found between current, wind direction and magnitude, defining that wind blows longshore and currents only flow proportionally in the same direction is an oversimplification (Winant, 1980; Cecílio, 2006). Wind blowing in the ocean generates a surface current initially in the same direction as the wind, but already in the second moment it deflects, due to the Ekman spiral (Ekman, 1905). This Ekman transport or pumping, as it is known, acts along the water column generating a deflection of the current in relation to the wind direction that increases as it moves away from the surface (Csanady, 1976; Scott \& Csanady, 1976). This explains, for example, the strong correlation found between the bottom cross-shore current and the surface longshore current (Figure 14 - A). Since this deflection goes to the left in the southern hemisphere, winds from the south quadrant generate currents flowing towards the coast, while northeast winds favoring the formation of a coastal jet to the oceanic region. Sea level changes in the coastal region then arise as the pressure field adjusts in geostrophic balance to longshore velocities (Cecílio, 2006).
The relationship between wind, current and sea level was identified in the correlation analyzes performed. The linear correlation between sea level and wind direction (in subtidal frequency) resulted in an average value of 0.48 for the three measured data stations. Cross-correlation analysis started on April 22 (first day of south wind) between level and component longshore wind indicated increasing correlation with sea level rise, peaking on the third day (0.64) south wind incidence (Figure 14 - B) indicating a significant, and out of phase, relationship. Cross-correlation of level with current indicated the same behavior, an increase in local sea level with currents blowing north (Figure 14 - C). On the other hand, the current also has a high frequency correlation with sea level. This is the influence of the semidiurnal cycle of the tide on the currents, especially in the transverse direction of the coast (Figure 14 - D).

\section{CONCLUSIONS}

The geomorphology of Santa Catarina Island and its surroundings provides the development of environments with diverse hydrodynamic characteristics. The forcing agents that dictate the magnitude and direction of the flow are impacted according to the shoreline designs, bathymetry and degree of protection of the ocean region. 
Coastal flow in the region is more dependent on transient weather conditions in the wind pattern than seasonal variations. The fixed high-pressure ocean system that generates a predominance of northeast quadrant winds is interrupted during the entry of cold fronts (frontal systems) with southern quadrant winds. Nevertheless, the intensification and/or displacement of both systems ends up generating a seasonal flow, especially in the outermost regions of Santa Catarina Island.

The resulting flow to the south makes the northern region of Santa Catarina Island a recipient of waters from the Arvoredo Biological Marine Reserve region, as well as supplier to North Bay. This predominant southward flow is most easily reversed during the fall.

Through the spectral decomposition of velocities, it was possible to identify larger contributions of the subtidal frequency in component $\mathrm{v}$ (north-south, longshore). In component u (east-west, cross-shore), the flow was conducted mainly by the tidal stream.

Current and local level presented a strong relation with the local wind pattern, indicating that the wind is the main forcing agent of the subtidal frequency. In the region, SASH and FMS alternate the prevailing wind regime between northeast ( $\mathrm{SASH}$ ) and south (FMSs or cold fronts). The northeast wind drains the flow to the south and causes local level lowering by geostrophic balance. Wind from the south, on the other hand, forces the currents to the north and stacks water on the coast, raising the local sea level.

Long monitoring campaigns with measured data are extremely important for understanding the processes that conduct the coastal hydrodynamics. Not only because they allow a detailed realistic analysis of each spectrum that forms that signal, but also, can serve as input or calibration data for numerical models that can evaluate flow at wider scales.

\section{ACKNOWLEDGEMENT}

The authors thank the Coordenação de Aperfeiçoamento de Pessoal de Nível Superior (CAPES) for supporting this research. We also thank the Companhia Catarinense de Águas e Saneamento (CASAN) and MAArE Project for providing data.

\section{REFERENCES}

Barletta, R. C., Ribeiro, P., Falkenberg, A. V., Maranhão, M. O. A., Franklin, L., \& Benedet, L. (2016). Physical Oceanographic measurements to support the outfall system design in the north of Santa Catarina Island, Brazil. In Proccedings of The International Symposium on Outfall Systems. Otawa.

Beardsley, R. C., Limebumer, R., \& Rosenfeld, L. K. (1985). Introduction to the CODE-2: moored array and large-scale data report. Northern California shelf. http://dx.doi.org/10.1575/1912/1641.

Bleninger, T., Falkenberg, A., Trevisan, A., Maranhão, M. O., Ishikawa, M., Ribeiro, P., \& Barletta, R. C. (2016). Combining measurements, models and decision support systems to optimize outfall sitting. In Proccedings of The DAE Special Edition - International Workshop Coastal Water Quality. Santos.
Bordin, L. H., Machado, E. C., Carvalho, M., Freire, A. S., \& Fonseca, A. L. D. O. (2019). Nutrient and carbono dynamics under the water mass seasonality on the continental shelf at the South Brazil Bight. Journal of Marine Systems, 189, 22-35. http:// dx.doi.org/10.1016/j.jmarsys.2018.09.006.

Brink, K. H. (1991). Coastal-trapped waves and wind-driven currents over the continental shelf. Annual Review of Fluid Mechanics, 23(1), 389-412. http://dx.doi.org/10.1146/annurev.fl.23.010191.002133.

Calado, L., Gangopadhyay, A., \& Silveira, I. C. A. (2008). Featureoriented regional modeling and simulations (FORMS) for the western South Atlantic: southeastern Brazil region. Ocean Modelling, 58(1-2), 48-64. http://dx.doi.org/10.1016/j.ocemod.2008.06.007.

Carvalho, J. L. B., Schettini, C. A. F., \& Ribas, T. M. (1998). Estrutura termohalina do litoral Centro-Norte Catarinense. Notas Técnicas Facimar, 2, 181-197.

Casares Pinto, E. (1998). Regime de correntes na plataforma continental externa de Santa Catarina (Thesis masters in physical oceanography). Universidade Federal do Rio Grande, Rio Grande.

Castro, B. M., \& Miranda, L. B. (1998). Physicl oceanography of the western Atlantic continental shelf located between $4^{\circ} \mathrm{N}$ and $34^{\circ} \mathrm{S}$. In AR Robinson \& KH Brink (Eds.), The sea: the global coastal ocean: processes and methods (pp. 209-252; chap. 11). Harvard: Harvard University Press.

Cecílio, R. O. (2006). Estrutura tridimensional das correntes geradas pelo vento na plataforma continental da região sul do Brasil (Thesis master in physical oceanography). Universidade de São Paulo, São Paulo.

Cirano, M., \& Lessa, G. C. (2007). Oceanographic characteristics of Baía de Todos os Santos, Brazil. Revista Brasileira de Geofísica, 25(4), 363-387. http://dx.doi.org/10.1590/S0102-261X2007000400002.

Csanady, G. (1976). Mean circulation on shallow seas. Journal of Geophysical Research, 81(30), 5389-5399. http://dx.doi.org/10.1029/ JC081i030p05389.

Ekman, V. W. (1905). On the influence of earth's rotation on ocean currents. Arkiv for Matematik. Astronomi Och Fysik, 2(11), 52.

Flagg, C. N., Vennersch, J. A., Beardsley, R. C. (1976). New England shelf dynamics experiment (March, 1974) - data report part II: the moored array. MIT.

Garbossa, L. H. P., Vanz, A., Fernandes, L. D. F., Souza, R. V., \& Vianna, L. F. (2014). Modelling and validation of the Santa Catarina Island Bays hydrodinamics based on astronomic tides and measured tides. In 11th International Conference on Hydroinformatics. New York. https://doi.org/10.13140/2.1.5123.6163.

Gregorio, H. P. (2014). Oscilaçôes subinerciais na plataforma continental sudeste: estudos numéricos (Thesis doctor in science). Universidade de São Paulo, São Paulo. http://dx.doi.org/10.11606/T.21.2014. tde-11032015-141317. 
Halpern, B. S., Walbridge, S., Selkoe, K. A., Kappel, C. V., Micheli, F., D’Agrosa, C., Bruno, J. F., Casey, K. S., Ebert, C., Fox, H. E., Fujita, R., Heinemann, D., Lenihan, H. S., Madin, E. M., Perry, M. T., Selig, E. R., Spalding, M., Steneck, R., \& Watson, R. (2008). A global map of human impact on marine ecosystems. Science, 319(5865), 948-952. PMid:18276889. http://dx.doi.org/10.1126/ science. 1149345.

Harari, J., \& Camargo, R. (1998). Modelagem numérica da região costeira de Santos (SP): circulação de maré. Revista Brasileira de Oceanografia, 46(2), 135-156. http://dx.doi.org/10.1590/S141377391998000200004 .

Harari, J., Cecílio, R. O., Coelho, T. M., \& Chixaro Neto, P. C. F. (2011). Numerical modeling of the hydrodynamics of Santa Catarina State - Southern Brazil. In Proccedings of The XI Safety, Health and Environment World Congress. Santos.

Hille, E., Schettini, C. A. F., \& Rodrigues-Ribeiro, M. (2008). Estrutura termohalina no litoral de Santa Catarina nos anos de 2005 e 2006. In ES Braga. (Ed.), Oceanografia e mudanças globais (pp. 371-382). São Paulo: Instituto Oceanográfico da Universidade de São Paulo.

Hirata, F. E. (2008). Variabilidade de nivel e correntes em baixa frequência na plataforma externa de Santa Catarina (Thesys doctorate in oceanography). Universidade do Rio Grande, Rio Grande.

Ito, E. R. K., \& Ambrizzi, T. (2000). Climatologia da posição da alta subtropical do atlântico sul para os meses de inverno. In Anais do XI Congresso Latinoamericano e Iberico de Meteorologia (pp. 860-865). Rio de Janeiro.

Lemos, C. F. \& Calbete, N. O. (1996). Sistemas frontais que atuaram no Brasil de 1987 a 1995 (Climanálise Especial; Edição comemorativa de 10 anos). MCT/INPE-CPTEC.

Lentz, S. J. (1994). Current dynamics over the Northern California Inner Shelf. Journal of Physical Oceanography, 24(12), 2461-2487. http://dx.doi.org/10.1175/1520-0485(1994)024<2461:CDOT $\mathrm{NC}>2.0 . \mathrm{CO} ; 2$.

Lima, J. A. M., Martins, R. P., Tanajura, C. A. S., Paiva, A. D. M., Cirano, M. C., Campos, E. J. D., Soares, I. D., França, G. B., Obino, R. D. S., \& Alvarenga, J. B. R. (2013). Design and implementation of the oceanographic modeling and observation network (REMO) for operational oceanography and ocean forecasting. Revista Brasileira de Geofísica, 31(2), 209-228. http://dx.doi.org/10.22564/ rbgf.v31i2.290.

Mann, K. H., \& Lazier, J. R. N. (2006). Dynamics of marine ecosystems: biological-physical interactions in the oceans (3th ed). Blackwell Publishing.

Matano, R. P., Palma, E. D., \& Piola, A. R. (2010). The influence of the Brazil and Malvinas Currents on the southwestern Atlantic shelf circulation. Ocean Science, 6(4), 983-995. http://dx.doi. org/10.5194/os-6-983-2010.
Mesquita, A. R., \& Harari, J. (2003). On the harmonic constants of tides and tidal currents of the South-eastern brazilian shelf. Continental Shelf Research, 23(11-13), 1227-1237. http://dx.doi. org/10.1016/S0278-4343(03)00107-9.

Mitchell, S. B., Jennerjahn, T. C., Vizzini, S., \& Zhang, W. (2015). Changes to processes in estuaries and coastal waters due to intense multiple pressures-An introduction and synthesis. Estuarine, Coastal and Shelf Science, 156, 1-6. http://dx.doi.org/10.1016/j. ecss.2014.12.027.

Monteiro, M. A. (2001). Caracterização climática do estado de Santa Catarina: uma abordagem dos principais sistemas atmosféricos que atuam durante o ano. Revista Geosul, 16(31), 69-78.

Noernberg, M., \& Alberti, A. L. (2014). Oceanographic variability in the inner shelf of parana, Brazil: spring condition. Revista Brasileira de Geofísica, 32(2), 197-206. http:/ / dx.doi.org/10.22564/ rbgf.v32i2.451.

Oliveira, A. S. (1986). Interações entre sistemas frontais na América do Sul e convecção na Amazônia (INPE-4008-TDL/239). INPE.

Oliveira, L. R., Piola, A., Mata, M. M., \& Soares, I. D. (2009). Brazil Current surface circulation and energetics observed from drifting buoys. Journal of Geophysical Research, 114(C10), C10006. http://dx.doi.org/10.1029/2008JC004900.

Palma, E. D., Matano, R. P., \& Piola, A. (2008). A numerical study of the Southwestern Atlantic Shelf circulation: stratified ocean response to local and offshore forcing. Journal of Geophysical Research, 113(C11), C11010. http://dx.doi.org/10.1029/2007JC004720.

Palma, E., Matano, R., \& Piola, A. (2004). A numerical study of the Southwestern Atlantic shelf circulation: barotropic response to tidal and wind forcing. Journal of Geophysical Research, 109(C8), C08014. http://dx.doi.org/10.1029/2004JC002315.

Pawlowicz, R., Beardsley, B., \& Lentz, S. (2002). Classical tidal harmonic analysis including error estimates in MATLAB using T_TIDE. Computers \& Geosciences, 28(8), 929-937. http://dx.doi. org/10.1016/S0098-3004(02)00013-4.

Pereira, J., Cirano, M., Almeida, M. M., \& Amorim, F. N. (2013). A regional study of the brazilian shelf/slope circulation (130-31॰S) using climatological open boundaries. Revista Brasileira de Geofísica, 31(2), 289-305. http://dx.doi.org/10.22564/rbgf.v31i2.295.

Pimenta, F. M., Melo, E., Franco, D., \& Zavialov, P. O. (2006). Assessment of Santa Catarina shelf currents through the analysis of indirect measurements. In Proccedings of the 8th International Coastal Symposium (pp. 651-655). Itajaí.

Rodrigues, M. L. G., Franco, D., \& Sugahara, S. (2004). Climatologia de frentes frias no litoral de Santa Catarina. Revista Brasileira de Geofisica, 22(2), 135-151. http://dx.doi.org/10.1590/S0102261X2004000200004. 
Saha, S., Moorthi, S., Wu, X., Wang, J., Nadiga, S., Tripp, P., Behringer, D., Hou, Y.-T., Chuang, H., Iredell, M., Ek, M., Meng, J., Yang, R., Mendez, M. P., van den Dool, H., Zhang, Q., Wang, W., Chen, M., \& Becker, E. (2014). The NCEP Climate Forecast System Version 2. Journal of Climate, 27(6), 2185-2208. http:/ / dx.doi.org/10.1175/JCLI-D-12-00823.1.

Scott, J., \& Csanady, G. (1976). Nearshore currents off Long Island. Journal of Geophysical Research, 81(30), 5401-5409. http:/ / dx.doi.org/10.1029/JC081i030p05401.

Segal, B., Freire, A. S., Lindner, A., Krajewski, J. P., \& Soldateli, M. (2017). MAArE - Monitoramento Ambiental da Reserva Biológica Marinha do Arvoredo e Entorno. Florianópolis: UFSC/MAArE.

Souza, R. B., \& Robinson, I. S. (2004). Lagrangian and satellite observations of the Brazilian Coastal Current. Continental Shelf Research, 24(2), 241-262. http://dx.doi.org/10.1016/j.csr.2003.10.001.

Stech, J. L., \& Lorenzzetti, J. A. (1992). The response of the South Brazil Bight to the passage of wintertime cold fronts. Journal of Geophysical Research, 97(6), 9507-9520. http://dx.doi. org/10.1029/92JC00486.

Tchernia, P. (1981). The Atlantic Ocean - descriptive regional oceanography (pp. 87-170). Oxford: Pergamon Press.

Winant, C. D. (1980). Coastal circulation and wind-induced currents. Annual Review of Fluid Mechanics, 12(1), 271-301. http:/ / dx.doi.org/10.1146/annurev.fl.12.010180.001415.
Zavialov, P., Moller Junior, O. O., \& Campos, E. J. D. (2002). First direct measurements of currents on the shelf of Southern Brazil. Continental Shelf Research, 22(14), 1975-1986. http://dx.doi. org/10.1016/S0278-4343(02)00049-3.

\section{Authors contributions}

Anna Luiza Pacheco Dalbosco: The first author wrote the entire article and performed data analysis with Professor Davide Franco.

Davide Franco: Technical responsible, as chief professor of the Marine Hydraulic Laboratory - UFSC, for the oceanographic data collection campaigns carried out by the MAArE project. This author performed the initial treatment of data obtained at Rebio Arvoredo (sea level, current and temperature). As well as assisted the first author in the statistical and spectral analysis of the data.

Rodrigo do Carmo Barletta: Responsible, as a consulting company manager, for the data collection project in the north of Santa Catarina Island subsidized by CASAN. It was also responsible for the initial processing of the level and current data. He was the main internal reviewer of the article.

Alexandre Bach Trevisan: As technical manager of CASAN, he managed with Rodrigo Barletta all the data collection in the north of Santa Catarina Island. Assisted in writing data collection methodology, discussion of results and reviews. 